\title{
PELAKSANAAN INVESTASI SUKUK DI INDONESIA: SEBUAH KAJIAN \\ AKUNTANSI DAN REGULASI
}

\author{
Febriyadi Tri Hadmoko \\ yadi.hadmoko@gmail.com \\ Eko Hadi Kusuma \\ ehadi12@yahoo.com \\ Amrie Firmansyah \\ amrie.firmansyah@gmail.com \\ Jurusan Akuntansi, Politeknik Keuangan Negara STAN
}

\begin{abstract}
This study aims to determine the implementation of SUKUK investment in Indonesia from accounting and regulation aspects. The research method used in this research is a qualitative method with content analysis. The steps are taken in this research use a literature study approach, namely by searching various written or online sources in the form of books, archives, magazines, articles, or documents relevant to be identified, classified, and concluded. The data and information are then elaborated as a basis for research analysis. The results showed that SUKUK's treatment in Indonesia, as regulated in PSAK 110, has accommodated sukuk issuers and sukuk users' needs. Furthermore, the regulations for the issuance and implementation of SUKUK in Indonesia are adequate, but there is still a need to strengthen the legal framework by refining existing policies. The results of this study indicate that the government and companies issuing SBSN need to increase promotion and education to the public concerning SUKUK so that Indonesian citizens are expected to have an interest in investing through SUKUK.
\end{abstract}

Keywords: Accounting, Law, sukuk

\section{ABSTRAK}

Penelitian ini bertujuan untuk mengetahui pelaksanaan investasi SUKUK di Indonesia dari aspek akuntansi dan regulasi. Metode penelitian yang digunakan dalam penelitian ini adalah metode kualitatif dengan analisis isi. Adapun langkah-langkah yang dilakukan dalam penelitian ini dengan menggunakan pendekatan studi literatur yaitu dengan melakukan pencarian terhadap berbagai sumber tertulis ataupun online baik berupa buku-buku, arsip, majalah, artikel, atau dokumendokumen yang relevan untuk diidentifikasikan, diklasifikasikan, dan disimpulkan. Data dan informasi tersebut selanjutnya dielaborasi sebagai dasar analisis penelitian. Hasil penelitian menunjukkan perlakuan SUKUK di Indonesia yang diatur dalam PSAK 110 sudah mengakomodir kebutuhan penerbit sukuk dan pengguna sukuk. Selanjutnya, regulasi untuk penerbitan dan pelaksanaan sukuk di Indonesia sudah memadai namun masih perlu dilakukan penguatan kerangka hukum melalui penyempurnaan pokok kebijakan yang sudah ada. Hasil penelitian ini mengindikasikan Pemerintah dan Perusahaan penerbit SBSN perlu meningkatkan promosi dan edukasi kepada masyarakat tentang sukuk, sehingga masyarakat diharapkan memiliki minat untuk berinvestasi melalui SUKUK.

Kata kunci: Akuntansi, Hukum, Sukuk.

\section{PENDAHULUAN}

Laporan Pew Research Center's Forum on Religion \& Public Life 2019 menunjukkan bahwa jumlah populasi Muslim dunia tahun 2020 sekitar 1,9 miliar (24,9 persen dari populasi dunia) dan diperkirakan tumbuh menjadi 2,7 miliar pada tahun 2050 atau sekitar 29,7 persen dari total penduduk dunia (globalreligiousfutures.org). Dilihat dari aspek marketing suatu produk atau jasa jumlah populasi yang besar tersebut sebanding dengan besarnya potensi pasar. Indonesia, sebagai negara dengan mayoritas penduduk muslim terbesar di dunia, memiliki potensi besar sebagai pusat pengembangan instrumen keuangan berbasis syariah. Aset instrumen keuangan syariah pada tahun 2017 diperkirakan menyentuh angka 2,431 triliun dolar AS (Global Islamic Finance Report). Bahkan di akhir tahun 2018 meningkat menjadi 2,591 triliun dolar AS atau meningkat sebesar 160 miliar dollar AS. 
Salah satu bentuk instrumen keuangan syariah yang paling berkembang pesat saat ini adalah sukuk. Di beberapa negara sukuk telah menjadi instrumen keuangan investasi dan pembiayaan anggaran negara yang penting. Beberapa negara seperti Malaysia, Bahrain, Brunei Darussalam, Mesir, Uni Emirat Arab, Qatar, Pakistan, Iran termasuk Indonesia, sudah menjadi issuer dari sukuk. Di Indonesia, pasar instrumen keuangan syariah khususnya sukuk tumbuh dengan cepat. Berdasarkan statistik sukuk syariah OJK per Januari 2019, investasi syariah sukuk berkembang sejak tahun 2013 sampai dengan 2019 sekitar 16 triliun rupiah naik menjadi 37 triliun rupiah. Hadirnya UU No. 19 tahun 2008 tentang Surat Berharga Syariah Negara diharapkan dapat mengakomodir pengembangan pasar keuangan syariah dalam negeri dan memberikan kesempatan bagi lembaga keuangan syariah untuk mengembangkan instrumen keuangan syariah khususnya sukuk. Hal ini menjadi peluang bagi perkembangan obligasi syariah terutama di Indonesia untuk menarik investor (Fatah, 2011).

Informasi diatas menunjukkan bahwa peluang investasi syariah khususnya sukuk telah banyak menarik minat para investor. Penerbitan sukuk, dilatarbelakangi oleh upaya menghindari praktik riba yang terdapat pada obligasi konvensional dan mencari alternatif sumber pembiayaan keuangan lain dengan prinsip syariah. Hal ini di dukung oleh munculnya fatwa ulama yang mengharamkan obligasi konvensional, seperti Fatwa Majma' al-Fiqh al-Islâmî 20 Maret 1990 dan Fatwa Dewan Syariah Nasional Majelis Ulama Indonesia No. 32/DSN-MUI/ IX/2002. Terkait dengan kebutuhan investasi jangka panjang, para ahli dan praktisi ekonomi Islam berijtihad untuk menciptakan sebuah produk atau instrumen keuangan baru yang bernama obligasi syariah atau sukuk (Fatah, 2011). Dari sisi standar akuntansi keuangan, PSAK 110 (IAI, 2011) tentang akuntansi sukuk telah disahkan pada tanggal 26 Oktober 2011. PSAK 110 hanya mengatur pengakuan, pengukuran, penyajian, dan pengungkapan transaksi sukuk ijarah dan sukuk mudharabah. Dari sisi perpajakan, Peraturan Pemerintah No 25 tahun 2009 tentang Pajak Penghasilan Kegiatan Usaha Syariah mengatur bahwa pemotongan pajak atas kegiatan Usaha Berbasis Syariah berlaku Mutatis Mutandis ketentuan UU PPh artinya perlakuan pajak obligasi syariah dipersamakan dengan obligasi konvensional. Peraturan pajak ini menyimpang mengingat penghasilan obligasi konvensional adalah bunga sedangkan obligasi syariah adalah prinsip bagi hasil (mudharabah atau murabahah).

Beberapa penelitian sebelumnya telah mengulas sejauh mana perkembangan obligasi syariah (sukuk) jika dilihat dari berbagai aspek. Penelitian sebelumnya menyatakan bahwa tantangan pengembangan sukuk sudah menjadi permasalahan klasik, tidak hanya terjadi pada sukuk saja akan tetapi terjadi pada instrumen investasi lainnya seperti saham syariah, reksadana syariah, pegadaian syariah, dan lainlain.

Permasalahan seperti ketidakpahaman masyarakat (investor) menimbulkan kecenderungan membandingkan pengembalian (return) antara instrumen syariah dengan konvensional. Hal ini tentu menyebabkan kegamangan praktisi untuk mendukung pengem bangan instrumen yang relatif baru ini (Fatah, 2011). Tantangan lain pengembangan sukuk seperti terbatasnya Sumber Daya Manusia dan pemahaman pelaku pasar, kurangnya sosialisasi produk syariah, masih terbatasnya produk akad dan produk pasar modal syariah, kurangnya regulasi pasar modal syariah, perlakuan sukuk tidak diatur dalam PSAK syariah menjadi PR dari pemerintah bila ingin mengembangkan pembiayaan berbasis syariah (Armadiyanti, 2013).

Penelitian lain mengungkapkan bahwa keberadaan sukuk negara pada perbankan syariah berpengaruh positif terhadap rasio nilai total pembiayaan perbankan syariah dan faktor lain berupa indikator makro ekonomi berupa nilai tukar rupiah terhadap USD dan inflasi masing-masing berpengaruh negatif dan positif terhadap perkembangan perbankan syariah Indonesia (Azwar, 2014). Jakarsih \& Rusdiyana (2009) menyimpulkan bahwa terdapat tantangan dalam pengembangan sukuk secara umum, mulai dari aspek syariah, kerangka hukum, regulasi, pasar, sampai kompleksitas produk. Kebijakan pemerintah dalam pengembangan sukuk mengikuti pola kebijakan bottom up approach sehingga mengembangkan pasar menjadi faktor kunci dalam menumbuhkan pasar sukuk di Indonesia. (Abubakar \& Handayani, 2017) berpendapat bahwa surat berharga syariah (sukuk) merupakan instrumen pasar modal yang berpotensi untuk dikembangkan baik sebagai 
alternatif investasi maupun pembiayaan. Perkembangan sukuk semakin meningkat dari tahun ke tahun namun, pangsa pasar sukuk masih belum signifikan. Strategi pengembangan sukuk masih terkendala regulasi sukuk seperti regulasi yang masih tersebar dan bersifat parsial serta belum terintegrasi. Dari beberapa penelitian diatas dapat dikatakan bahwa perkembangan obligasi sukuk masih terkendala pada aspek umum seperti kurang sosialisasi, kurang jelasnya aturan, dan kondisi ekonomi makro.

Penelitian ini bertujuan untuk mengulas perkembangan sukuk jika dilihat dari aspek akuntansi dan aspek hukum berupa analisis terkait kebijakan regulasi seputar sukuk dan perlakuan akuntansi sukuk di Indonesia. Perbedaan dengan penelitian sebelumnya adalah fokus penelitian yang spesifik terhadap sukuk yang hanya dilihat dari aspek hukum dan akuntansi. Manfaat dari penelitian ini diharapkan dapat menjadi rujukan bagi peneliti selanjutnya, memberikan masukan terkait perkembangan obligasi syariah (sukuk) dari segi akuntansi dan hukum.

\section{TINJAUAN PUSTAKA}

Menurut IFRS 7 (IASB, 2011), instrumen keuangan didefinisikan sebagai kontrak yang dapat menimbulkan aset keuangan dan kewajiban keuangan atau instrumen ekuitas bagi entitas lainnya. Aset keuangan terdiri dari kas, instrumen ekuitas entitas lain, hak kontraktual untuk menerima kas atau aset keuangan lainnya dari entitas lain atau untuk menukarkan aset keuangan atau kewajiban keuangan dengan entitas lain yang persyaratan/kondisinya mungkin menguntungkan bagi entitas sendiri, kontrak yang akan atau mungkin diselesaikan dalam instrumen ekuitas entitas yang diterbitkan oleh. Untuk tujuan tersebut, instrumen ekuitas entitas sendiri tidak termasuk instrumen yang merupakan kontrak untuk penerimaan masa depan atau pengiriman instrumen ekuitas entitas tersebut.

Investasi merupakan suatu kegiatan menempatkan dana pada lebih dari satu asset selama periode tertentu dengan harapan dapat memperoleh penghasilan dan atau peningkatan nilai investasi (Adrian, 2011). Hartono (1998) membagi investasi menjadi dua yaitu investasi langsung dan investasi tak langsung. Investasi langsung dilakukan dengan membeli langsung aktiva keuangan dari suatu perusahaan baik melalui perantara atau dengan cara lain, sedangkan investasi tak langsung dilakukan dengan membeli surat-surat berharga dari perusahaan investasi. Selanjutnya, Jones (1996) menyatakan bahwa investasi adalah suatu kegiatan penempatan dana pada satu atau lebih dari satu asset selama periode tertentu dengan harapan dapat memperoleh penghasilan atau peningkatan nilai investasi. Dari pengertian investasi diatas dapat dikatakan bahwa memegang kas atau uang bukan merupakan investasi, sedangkan menabung di bank merupakan investasi karena mendapatkan return atau keuntungan. Pada umumnya investor mempunyai kecenderungan tidak menyukai risiko (risk averse) yakni mereka yang hanya berani mengambil risiko dalam tingkat yang relatif rendah dengan imbal hasil yang juga relatif rendah dalam Irkhami, 2010). Adrian (2011) menyatakan bahwa semakin tinggi risiko suatu kesempatan investasi, maka semakin tinggi pula tingkat keuntungan yang disyaratkan oleh investor. Konsep ini juga berlaku pada investasi dalam saham maupun obligasi.

Obligasi merupakan kontrak jangka panjang dimana peminjam dana setuju untuk membayar bunga dan pokok pinjaman pada tanggal tertentu kepada pemegang obligasi tersebut (Brigham, 2009). Menurut bursa efek Indonesia, surat utang (obligasi) merupakan surat utang jangka menengah panjang yang dapat dipindahtangankan, berisi janji dari pihak yang menerbitkan untuk membayar imbalan berupa bunga pada periode tertentu dan melunasi pokok utang pada waktu yang telah ditentukan kepada pihak pembeli (investor). Obligasi direpresentasikan sebagai janji untuk membayar sejumlah uang pada waktu jatuh tempo ditambah tingkat bunga periodik tertentu nilai obligasi (Maharti, 2011). Dengan demikian, obligasi merupakan surat utang atau perjanjian resmi dari penerbit obligasi ke pembeli obligasi untuk membayar sejumlah uang pada waktu tertentu dengan jumlah yang disepakati.

Obligasi syariah merupakan suatu surat berharga jangka panjang berdasarkan prinsip syariah yang dikeluarkan Emiten kepada pemegang Obligasi Syariah dengan pengembalian berupa bagi hasil/margin/fee serta membayar kembali dana obligasi pada saat jatuh tempo. Di Indonesia, obligasi syariah hanya sedikit dikenal dengan nama sukuk. Namun, sejak peraturan Badan Pengawas Pasar 
Modal dan Lembaga Keuangan (BAPEPAM) No. IX.13.A mengenai Penerbitan Efek Syariah dan ditetapkannya UU. No.19 Tahun 2008 tentang Surat Berharga Syariah Negara, istilah sukuk menjadi lebih sering digunakan.

Kata sukuk berasal dari bahasa arab "shukuk", merupakan bentuk jamak dari kata "shakk" dalam istilah ekonomi berarti legal instrumen, deed, atau check. Secara substansial obligasi merupakan surat utang dalam ekonomi konvensional dan obligasi syariah merupakan surat utang berbasis prinsip syariah. Sistem pengembalian pada obligasi syariah adalah bagi hasil, margin, dan fee, sedangkan pada obligasi konvensional sistem pengembaliannya adalah sistem bunga. Karakteristik umum obligasi syariah atau sukuk sebagaimana (Jakarsih \& Rusdiyana, 2009) adalah Tradable yaitu sukuk mewakili pihak pemilik aktual dari aset, manfaat aset, atau kegiatan bisnis, dan dapat diperdagangkan menurut harga pasar (market price), Rateable yaitu sukuk dapat diperingkat oleh agen pemeringkat, baik regional maupun internasional, Enhanceable yakni Sukuk dapat dijamin dengan jaminan (collateral) lain berdasarkan prinsip syariah karena sukuk didasarkan pada underlying asset atau aktivitas bisnis, Legal Flexibility yakni sukuk dapat ditawarkan secara nasional dan global dengan perlakuan pajak yang berbeda, Redeemable yakni Sukuk memungkinkan dapat ditebus.

Apabila dibandingkan dengan instrumen keuangan investasi secara konvensional, sukuk dan obligasi konvensional memiliki beberapa perbedaan antara lain sebagai berikut:

Tabel 1. Perbandingan Karakteristik sukuk dan obligasi konvensional

\begin{tabular}{lll}
\hline Pembanding & \multicolumn{1}{c}{$\begin{array}{c}\text { Sukuk(Obligasi } \\
\text { Syariah) }\end{array}$} & $\begin{array}{c}\text { Obligasi } \\
\text { Konvensional }\end{array}$ \\
\hline $\begin{array}{l}\text { Prinsip } \\
\text { dasar }\end{array}$ & $\begin{array}{l}\text { Surat berharga yang } \\
\text { diterbitkan berdasarkan } \\
\text { prinsip syariah, sebagai } \\
\text { bukti } \\
\text { kepemilikan/penyertaan } \\
\text { terhadap suatu asset }\end{array}$ & $\begin{array}{l}\text { Pernyataan } \\
\text { utang tanpa } \\
\text { syarat dari } \\
\text { penerbit }\end{array}$ \\
& $\begin{array}{l}\text { yang menjadi dasar } \\
\text { penerbitan sukuk }\end{array}$ & \\
& $\begin{array}{l}\text { Memerlukan } \\
\text { Underlying } \\
\text { Asset }\end{array}$ & Tidak ada \\
& sebagai dasar & \\
penerbitan & \\
Fatwa/opini & Memerlukan & Tidak ada \\
syariah & fatwa/opini syariah & \\
& untuk menjamin &
\end{tabular}

kesesuaian sukuk

dengan prinsip syariah

$\begin{array}{lll}\begin{array}{l}\text { Penggunaan } \\ \text { Dana }\end{array} & \begin{array}{l}\text { Tidak dapat digunakan } \\ \text { untuk hal-hal yang } \\ \text { bertentangan degan } \\ \text { prinsip syariah }\end{array} & \text { Bebas } \\ \text { Return } & \begin{array}{l}\text { Berupa imbalan, bagi } \\ \text { hasil, margin, capital } \\ \text { gain }\end{array} & \begin{array}{l}\text { Bunga, } \\ \text { capital gain }\end{array} \\ \text { Jangka } & \text { Pendek-menengah } & \begin{array}{l}\text { Menengah- } \\ \text { Panjang } \\ \text { Kaktu }\end{array} \\ \text { Investor } & \text { Islami, konvensional } & \text { Konvional }\end{array}$

Sumber: Wawancara dengan Direktorat Jenderal

Pembiayaan dan Risiko

\section{METODE PENELITIAN}

Penelitian ini menggunakan pendekatan kualitatif dengan analisis isi. Adapun langkah-langkah yang dilakukan dalam penelitian ini dengan menggunakan pendekatan studi literatur yaitu dengan melakukan pencarian terhadap berbagai sumber tertulis ataupun online baik berupa buku-buku, arsip, majalah, artikel, atau dokumen-dokumen yang relevan untuk diidentifikasikan, diklasifikasikan, dan disimpulkan. Data dan informasi tersebut selanjutnya dielaborasi sebagai dasar analisis penelitian. Dari tahapan tersebut dapat diperoleh kesimpulan sementara, untuk selanjutnya dielaborasi dengan berbagai literatur terkait. Selain itu, beberapa data diperoleh dari situs www.idx.co.id, www.djppr.kemenkeu.go.id, www.dsnmui.or.id.

\section{HASIL DAN PEMBAHASAN}

Skema Sukuk (Obligasi Syariah)

Atas penerbitan sukuk ijarah, emiten mengalihkan manfaat obyek ijarah kepada investor, dan investor yang diwakili amanat sukuk menerima manfaat obyek ijrah (berupa fixed asset yang sudah ada dengan jenis asset dan spesifikasi jelas) dari emiten. Investor yang diwakili wali amanat sukuk memberikan kuasa (akad wakalah) kepada emiten untuk menyewakan obyek ijarah tersebut kepada pihak ketiga. Emiten selaku penerima kuasa dari investor bertindak sebagai pemberi sewa (mu'jir) menyewakan obyek ijarah tersebut kepada pihak ketiga sebagai penyewa (musta'jir). Atas obyek ijarah yang disewa tersebut, pihak ketiga memberikan pembayaran sewa kepada emiten. Selanjutnya, emiten meneruskan pembayaran sewa yang diterima dari pihak ketiga kepada investor berupa cicilan fee ijarah pada saat jatuh tempo sukuk. 
Sebagai gambarang umum, skema umum sukuk ijarah adalah sebagai berikut:

Gambar 1. Skema Umum Sukuk

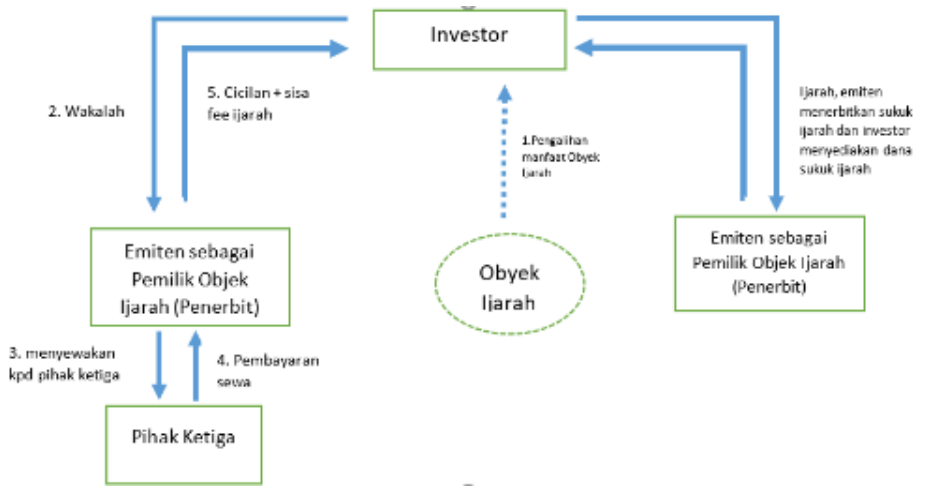

Sumber : Himpunan Skema sukuk Kementerian Keuangan

\section{Perkembangan Sukuk di Indonesia}

Sukuk di Indonesia, pertama kali diterbitkan oleh PT Indonesian Satellite Corporation (Indosat) pada bulan September tahun 2002 dengan nilai Rp 175 miliar. Langkah Indosat tersebut diikuti perusahaan perusahaan besar lainnya. Nilai penerbitan sukuk korporasi hingga akhir 2008 mencapai 4,76 triliun. Sedangkan struktur sukuk yang digunakan pada periode 2002-2004 lebih didominasi oleh mudharabah sebesar Rp 740 miliar (88\%), sisanya ijarah sebesar Rp 100 miliar (12\%). Adapun periode 2004-2007 didominasi oleh ijarah sebesar Rp 2,194 triliun (92\%), sisanya mudharabah sebesar Rp 200 miliar (8\%) (Fatah, 2011).

Enam sukuk yang sudah dipasarkan adalah sukuk ijarah, Aneka Gas Industri Indosat (Rp160 miliar), sukuk ijarah Indosat III (Rp570 miliar), sukuk ijarah Metrodata Electronics (Rp90 miliar), sukuk ijarah Summarecon Agung (Rp200 miliar), sukuk ijarah Bank Muamalah (Rp134 miliar), sukuk ijarah Mayora Indah (Rp200 miliar). Saat ini pangsa pasar sukuk memang belum besar. Menurut catatan PT Danareksa Sekuritas, outstanding sukuk baru 3\% dari total pasar sukuk di Indonesia, sebanyak 97\% lainnya masih dikuasai obligasi konvensional. (Fatah, 2011).

Setelah disahkannya UU SBSN tahun 2008, Pemerintah menerbitkan sukuk sebesar $\mathrm{Rp} 15$ triliun. Penerbitan sukuk ini dilaksanakan sebagai bagian dari pembiayaan defisit anggaran dalam APBN tahun 2008. Penerbitan sukuk perdana ini telah dilaksanakan di dalam dan luar negeri. Besarnya sukuk sesuai dengan underlying aset yang dimiliki pemerintah senilai Rp 15 triliun.
Pemerintah menggunakan jaminan berupa aset milik negara, seperti tanah dan bangunan. Pemerintah mendahulukan penerbitan sukuk di dalam negeri, setelah itu baru ke pasar internasional. Setengah penerbitan sukuk akan dilakukan di dalam negeri dan sisanya ke pasar internasional (Fatah, 2011).

Sukuk telah mengalami perkembangan pesat baik dalam kuantitas dan kualitas. Namun, penerapan sukuk negara (sovereign sukuk) belum seaplikatif penerapan sukuk swasta (corporate sukuk). Ada beberapa kendala yang urgen untuk ditangani seperti masalah fiskal dan perundang-undangan (Yaumuddin, 2008). Sehingga, penerbitan sukuk pemerintah baru dilakukan setelah terbit undang-undang tentang Surat Berharga Syariah Negara (SBSN) pada tahun 2008. Sukuk diterbitkan oleh negara (sovereign sukuk) mengacu pada peraturan perundang-undangan. (Fasa, 2016).

Berdasarkan statistik pasar modal syariah yang dikeluarkan oleh Direktorat Pasar Modal Syariah - Otoritas Jasa Keuangan, sejak tahun 2008, emisi sukuk selalu mengalami peningkatan, baik dari total jumlah maupun total nilainya. Sementara untuk sukuk outstanding, secara umum mengalami peningkatan kecuali pada tahun 2011 dan 2014. Pada tahun 2008, emisi suku tercatat berjumlah 29 dengan total nilai 5.498,00 miliar sedangkan pada tahun 2019*, emisi sukuk berjumlah 232 dengan total nilai $48.240,40$ miliar. Hal ini berlaku juga pada sukuk outstanding, dimana pada tahun 2008 sukuk outstanding berjumlah 24 dengan total nilai 4.958,40 miliar sementara pada tahun 2019* sukuk outstanding berjumlah 145 dengan total nilai mencapai $30.203,50$ miliar. Jumlah sukuk selama periode 20082019 baik untuk emisi suku maupun sukuk outstanding, dapat dilihat secara lebih jelas pada tabel 2 . 
Tabel 2. Data Perkembangan Sukuk di Indonesia Tahun 2008-2019

\begin{tabular}{|l|l|r|r|r|}
\hline Tahun & \multicolumn{2}{|l|}{ Emisi Sukuk } & \multicolumn{2}{l|}{ Sukuk Outstanding } \\
\hline & $\begin{array}{l}\text { Total Nilai } \\
\text { (dalam } \\
\text { Miliar }\end{array}$ & Jml & $\begin{array}{l}\text { Total Nilai } \\
\text { (dalam } \\
\text { Miliar) }\end{array}$ & Jml \\
\hline 2008 & $5.498,00$ & 29 & $4.958,40$ & 24 \\
\hline 2009 & $7.015,00$ & 43 & $5.621,40$ & 30 \\
\hline 2010 & $7.815,00$ & 47 & $6.121,00$ & 32 \\
\hline 2011 & $7.915,40$ & 48 & $5.876,00$ & 31 \\
\hline 2012 & $9.790,40$ & 54 & $6.883,00$ & 32 \\
\hline 2013 & $11.994,40$ & 64 & $7.553,00$ & 36 \\
\hline 2014 & $12.917,40$ & 71 & $7.144,00$ & 35 \\
\hline 2015 & $16.114,00$ & 87 & $9.902,00$ & 47 \\
\hline 2016 & $20.425,40$ & 100 & $11.878,00$ & 53 \\
\hline 2017 & $26.394,90$ & 137 & $15.740,50$ & 79 \\
\hline 2018 & $36.545,40$ & 177 & $22.023,00$ & 104 \\
\hline $2019 *$ & $48.240,40$ & 232 & $30.203,50$ & 145 \\
\hline
\end{tabular}

* total s.d. bulan November 2019

Sumber: Diolah dari Data Produk Obligasi Syariah Otoritas Jasa Keuangan

Meskipun dalam perkembangannya, emisi sukuk selalu mengalami peningkatan, namun di Indonesia masih menghadapi tantangan - tantangan. Terdapat tantangan tantangan yang dapat diidentifikasi terkait dengan emisi sukuk. Pertama, tidak adanya standarisasi fatwa mengenai struktur produkproduk instrument syariah dari masing-masing negara dan standar AAOIFI belum digunakan sebagai acuan oleh semua yang penduduknya mayoritas muslim. (Fatah, 2011). Kedua, kurangnya pemahaman masyarakat akan keberadaan sukuk (Fatah, 2011). Ketiga, faktor promosi dan iklan dalam dunia investasi di pasar modal (Yuliati, 2011).

\section{Aspek Akuntansi}

Menurut (Harahap, 2017) faktor-faktor penyebab percepatan perkembangan akuntansi antara lain: pertama, keinginan untuk mendapatkan keuntungan besar diperlukan pencatatan dan pengikhtisaran dengan cara sistematis dengan ukuran satuan moneter serta dapat menjelaskan keterjadiannya. Kedua, pentingnya aspek sosial yakni pemimpin perusahaan harus membuat keputusan yang menjaga keseimbangan antara keinginan perusahaan, pegawai, langganan, supplier, dan customer. Ketiga, akuntansi memberikan informasi potensial yang berguna untuk membuat keputusan yang akan berpengaruh dalam kesejahteraan sosial.
Menurut

(Hasibuan, 2014)

Perkembangan akuntansi syariah di Indonesia tidak dapat dilepaskan dari proses pendirian Bank Syariah. Pendirian Bank Muamalat Indonesia (BMI) merupakan landasan awal diterapkannya ajaran Islam menjadi pedoman bermuamalah. Pendirian ini dimulai dengan serangkaian proses perjuangan sekelompok masyarakat dan para pemikir Islam dalam upaya mengajak masyarakat Indonesia bermuamalah yang sesuai dengan ajaran agama. Kelompok ini diprakarsai oleh beberapa orang tokoh Islam, Ikatan Cendekiawan Muslim Indonesia (ICMI), serta Majelis Ulama Indonesia (MUI) yang pada waktu itu, sekitar tahun 1990.

Selanjutnya, perkembangan akuntansi syariah di Indonesia, seperti yang dikatakan Amin Musa, dilatarbelakangi banyaknya transaksi dengan dasar prinsip syariah, baik yang dilakukan lembaga bisnis syariah maupun non syariah (Harahap, 2017). Banyaknya transaksi syariah perlu adanya strandardisasi pencatatan, pengukuran, dan pengungkapan sampai dengan penyajian sehingga antara pembuat dan pengguna laporan keuangan mempunyai pemahaman yang sama. Di Indonesia produk standar akuntansi keuangan syariah terdiri dari PSAK 59 untuk perbankan syariah saja sedangkan di sisi Lembaga Keuangan Syariah non-Bank telah berkembang dengan dibentuknya Komite Akuntansi Syariah (KAS) agar dapat menyusun penerbitan PSAK Syariah yang akan digunakan oleh semua entitas syariah. Mulai tahun 2008 Komite Akuntansi Syariah mengesahkan PSAK syariah dimulai dari PSAK 101 sampai dengan 106 dan kerangka dasar penyusunan dan penyajian lembaga keuangan syariah yang terpisah dengan PSAK dan kerangka dasar akuntansi non syariah. Sampai saat ini standar akuntansi keuangan syariah telah berkembang sampai dengan PSAK 110 tentang sukuk. Pengembangan Standar Akuntansi Syariah dilakukan dengan mengikuti model Standar Akuntansi Keuangan umum namun berbasis syariah dengan mengacu kepada fatwa MUI (SAS, 2020).

Menurut PSAK 110, sukuk merupakan efek syariah berupa sertifikat atau bukti kepemilikan yang bernilai sama dan mewakili bagian yang tidak tertentu (tidak terpisahkan atau tidak terbagi) atas aset berwujud tertentu, manfaat atas aset berwujud tertentu baik yang sudah ada maupun yang akan ada, jasa yang 
sudah ada maupun yang akan ada, aset proyek tertentu, dan kegiatan investasi yang telah dilakukan. Pada umumnya jenis jenis sukuk didasarkan pada akad atau perjanjian antara pihak yang disusun berdasarkan prinsip syariah. Obligasi syariah atau sukuk juga terbebas dari unsur riba, gharar, dan maysir.

Berikut disajikan beberapa hal tentang perlakuan sukuk berdasarkan PSAK 110 tentang sukuk (Zakiya \& Siswantoro, 2014) sebagaimana terdapat pada tabel 3

Tabel 3. PSAK 110

\begin{tabular}{|l|l|}
\hline \multicolumn{1}{|c|}{ Kriteria } & \multicolumn{1}{|c|}{ PSAK 110 } \\
\hline $\begin{array}{l}\text { Klasifikasi } \\
\text { utang }\end{array}$ & $\begin{array}{l}\text { PSAK 110 hanya mengatur tentang sukuk } \\
\text { ijarah dan sukuk mudharobah. }\end{array}$ \\
\hline $\begin{array}{l}\text { Basis } \\
\text { akuntansi }\end{array}$ & Akrual. \\
\hline Pengakuan & $\begin{array}{l}\text { Sukuk ijarah diakui penerbit pada saat } \\
\text { entitas menjadi pihak yang terikat dengan } \\
\text { ketentuan penerbit sukuk ijarah. }\end{array}$ \\
\hline Pengukuran & $\begin{array}{l}\text { Sukuk ijarah diakui sebesar nominal dan } \\
\text { biaya transaksi. }\end{array}$ \\
\hline $\begin{array}{l}\text { Amortisasi } \\
\text { diskonto dan } \\
\text { premium }\end{array}$ & $\begin{array}{l}\text { Amortisasi diskon dan premium } \\
\text { menggunakan metode garis lurus, } \\
\text { sepanjang periode sukuk ijarah. }\end{array}$ \\
\hline Penyajian & $\begin{array}{l}\text { Sukuk ijarah disajikan sebagai liabilitas. } \\
\text { Sukuk ijarah disajikan secara neto setelah } \\
\text { premium atau diskonto dan biaya } \\
\text { transaksi yang belum diamortisasi. }\end{array}$ \\
\hline Pengungkapan & $\begin{array}{l}\text { a) Ringkasan akad syariah yang } \\
\text { digunakan. b) Aset atau manfaat yang } \\
\text { mendasari. c) Besaran imbalan. d) Nilai } \\
\text { nominal. e) Jangka waktu. d) Persyaratan } \\
\text { penting lainnya. e) Penjelasan mengenai } \\
\text { aset atau manfaat yang mendasari } \\
\text { penerbitan sukuk ijarah, termasuk jenis } \\
\text { dan umur ekonomis. }\end{array}$ \\
\hline $\begin{array}{l}\text { Akad Ijarah, akad Mudharabah, akad } \\
\text { Salam, akad Musyarakah, akad Istishna, } \\
\text { akad Murabahah, akad Wakalah, akad } \\
\text { Muzara'ah, akad Musaqah. }\end{array}$ \\
\hline Jenis Akad
\end{tabular}

Sumber: Zakiya dan Siswantoro, 2014

Perlakuan akuntansi untuk sukuk di Indonesia saat ini sudah mengacu pada PSAK 110. PSAK ini mengakomodir kebutuhan pemahaman antara penerbit sukuk dan pengguna sukuk (investor) tentang pengakuan dan pengukuran dalam pencatatan atas transaksi sukuk, serta penyajian sukuk dan sekaligus pengungkapan yang disyaratkan untuk dipenuhi. PSAK 110 juga mengakomodasi untuk sukuk dengan akad ijarah dan sukuk dengan akad mudharabah serta jenis akad sukuk lainnya. Hal ini menunjukkan bahwa perkembangan penerbitan sukuk tidak terkendala dari aspek akuntansi.

\section{Aspek Regulasi}

Istilah obligasi konvensional merupakan istilah penetapan utang dari pemilik/pihak yang mengeluarkan obligasi atas suatu proyek dan memberikan hak bunga kepada pemegangnya sesuai kesepakatan di samping nilai pelunasan obligasi saat jatuh tempo atau habis masa utang. Jadi pemegang obligasi menerima beberapa hak sebagai berikut: pertama, Hak mendapatkan bunga sesuai kesepakatan, kedua, hak pengembalian nilai obligasi saat jatuh tempo, ketiga, hak untuk mengedarkan obligasi dengan menjualnya kepada orang lain (Faniyah, 2018). Sehingga terlihat jelas bahwa obligasi adalah riba yang diharamkan dalam Al-Qur'an maupun Al Hadits. Dalam al Qur'an pelarangan terhadap riba terdapat dalam QS: Al-Baqarah: 278-279. Bunga adalah tambahan yang dikenakan dalam transaksi pinjaman uang yang diperhitungkan dari pokok pinjaman tanpa mempertimbangkan pemanfaatan/hasil pokok tersebut. Riba adalah tambahan tanpa imbalan yang terjadi karena penangguhan dalam pembayaran yang diperjanjikan sebelumnya (Faniyah, 2018). Firman dalam Al-Qur'an tersebut oleh Majelis Ulama Indonesia diaplikasikan dalam Obligasi syariah dengan Fatwa MUI Nomor 32/DSN-MUI/IX/2002 tentang Obligasi Syariah, disebutkan bahwa: a) Obligasi yang tidak dibenarkan menurut syariah adalah obligasi yang bersifat utang dengan kewajiban membayar berdasarkan bunga; b) Obligasi yang dibenarkan menurut syariah adalah obligasi berdasarkan prinsipprinsip syariah; dan c) Obligasi syariah adalah suatu surat berharga jangka panjang berdasarkan prinsip syariah yang dikeluarkan emiten kepada pemegang obligasi syariah yang mewajibkan emiten untuk membayar pendapatan kepada pemegang obligasi syariah berupa bagi hasil/margin/fee serta membayar kembali dana obligasi pada saat jatuh tempo.

Dalam hukum positif Indonesia, sukuk sebagai surat berharga syariah dikukuhkan dalam Fatwa DSN No : 32 /DSNMUI/IX/2002, yang mendefinisikan sukuk atau obligasi syariah sebagai "suatu surat berharga jangka panjang berdasarkan prinsip syariah yang dikeluarkan emiten kepada 
pemegang obligasi syariah yang mewajibkan emiten untuk membayar pendapatan kepada pemegang obligasi syariah berupa bagi hasil/margin/fee serta membayar kembali dana obligasi pada saat jatuh tempo". Selanjutnya, sebagai instrumen keuangan sukuk berkaitan dengan beberapa hal, yakni merupakan surat berharga, keikutsertaan investasi, ada underlying assets, kupon menjadi bagi hasil, segmentasi syariah dan non syariah, emiten kriteria jakarta islamic indeks (jii), dan dicatat sebagai investment account. Fatwa MUI lain yakni Fatwa DSN Nomor 33/DSNMUI/IX/2002 tentang Obligasi Syariah Mudharabah dan Fatwa DSN Nomor 41/DSNMUI/IX/2002 tentang Obligasi syariah Ijarah (Abubakar dan Handayani, 2017).

Fatwa DSN MUI berdasarkan hukum Indonesia tidak termasuk dalam hierarki peraturan perundang-undangan, maka fatwa DSN MUI tersebut perlu diintegrasikan ke dalam peraturan Bapepam. Dalam proses selanjutnya, Bapepam dan LK (kini OJK) melakukan sinkronisasi dan harmonisasi fatwa DSN MUI tersebut ke dalam aturan OJK lewat penerbitan aturan baru atau merevisi aturan yang sudah ada. Peraturan terkait pasar modal syariah diterbitkan Bapepam pertama kali tahun 2006, yaitu Peraturan Nomor IX.A.13 tentang Penerbitan Efek Syariah dan Peraturan Nomor IX.A.14 tentang Akad-akad yang Digunakan dalam Penerbitan Efek Syariah. Selanjutnya pada tahun 2007 diterbitkan Peraturan Nomor II.K.1 tentang Kriteria dan Penerbitan Daftar Efek Syariah. Dengan berkembangnya pasar modal syariah, Peraturan Nomor IX.A.13 dan Peraturan Nomor IX.A.14 mengalami penyempurnaan pada tahun 2009 (Hudiata, 2017).

Selain Fatwa DSN-MUI, pemerintah menerbitkan Undang-Undang No. 19 Tahun 2008 Tentang Surat Berharga Syariah Negara (SBSN). Dengan diterbitkannya undangundang tersebut, maka landasan hukum bagi pemerintah untuk melakukan percepatan pembangunan seharusnya sudah kokoh, tinggal bagaimana kemauan pemerintah (political will) untuk menggunakan dan mengoptimalkan sukuk, baik sukuk negara maupun korporasi sebagai alternatif pembiayaan pembangunan. Sementara dari sisi perpajakan, pemerintah sudah mengesahkan Peraturan Pemerintah No 25 tahun 2009 tentang Pajak Penghasilan Kegiatan Usaha Syariah.
Menteri Keuangan selanjutnya mengeluarkan Peraturan Menteri Keuangan Nomor 218/PMK/2008 tentang Penerbitan dan Penjualan Surat Berharga Syariah Negara Ritel di Pasar Perdana Dalam Negeri. Di dalam aturan tersebut, penerbitan sukuk Negara ritel di pasar perdana dalam negeri dapat dilaksanakan oleh secara langsung oleh pemerintah atau melalui perusahaan penerbit SBSN.

Tahun 2015, Otoritas Jasa Keuangan mengeluarkan Peraturan Otoritas Jasa Keuangan (POJK) No. 18/POJK.04/2015 Tentang Penerbitan dan Persyaratan Sukuk. Sesuai peraturan tersebut, sukuk merupakan efek syariah berupa sertifikat atau bukti kepemilikan yang bernilai sama dan mewakili bagian yang tidak terpisahkan atau tidak terbagi (syuyu'/undivided share) atas aset yang mendasarinya.

Penerbitan peraturan-peraturan terkait sukuk yang menjadi landasan atau payung hukum bagi penerbitan sukuk di Indonesia saat ini bisa dikatakan sudah memadai dari segi jumlah dan jenis peraturan. Hal ini dapat dilihat dari jenis-jenis peraturan yang telah terbit seperti yang sudah diuraikan sebelumnya. Selain fatwa Dewan Syariah Nasional MUI, sudah diterbitkan Undang-Undang, Peraturan Pemerintah, Peraturan Menteri Keuangan, dan Peraturan Otoritas Jasa Keuangan yang mengatur atau berkaitan dengan sukuk.

Akan tetapi, dari produk-produk hukum yang telah diterbitkan tersebut masih terdapat beberapa hal yang kurang selaras, perlu dibenahi, dan dikuatkan kerangka hukumnya. Yakni, Peraturan Pemerintah No 25 tahun 2009 tentang Pajak Penghasilan Kegiatan Usaha Syariah yang dapat menimbulkan dua konsekuensi. Pertama, Peraturan Pemerintah tersebut menyebutkan bahwa pemotongan pajak atas kegiatan Usaha Berbasis Syariah berlaku Mutatis Mutandis ketentuan UU PPh artinya perlakuan pajak obligasi syariah dipersamakan dengan obligasi konvensional. Kedua, prinsip obyek pemotongan pajak atas obligasi konvensional masih didasarkan pada pengembalian (return) berupa bunga, sedangkan, prinsip pengembalian (return) obligasi syariah (sukuk) berupa bagi hasil, margin, atau laba. Hal ini dapat menimbulkan ambiguitas pemahaman di masyarakat atau calon investor, sehingga dapat menurunkan minat investor dalam menginvestasikan dana ke obligasi syariah (sukuk). 
Selain itu, diperlukan penguatan kerangka hukum dalam rangka menghadapi perkembangan sukuk agar sukuk mampu bersaing di level global dan meningkatkan kepercayaan masyarakat dan investor, sehingga mampu meningkatkan pertumbuhan penerbitan sukuk. Penguatan kerangka hukum tersebut dapat berupa penyempurnaan terhadap produk hukum yang sudah ada atau penerbitan produk hukum baru. Mengingat bahwa produk hukum yang ada saat ini dari segi jumlah dan jenis sudah memadai, akan lebih baik jika mengambil opsi untuk melakukan penyempurnaan produk hukum yang sudah ada.

\section{KESIMPULAN}

Berdasarkan pembahasan yang telah dilakukan, penulis mengambil simpulan bahwa penerbitan sukuk di Indonesia berkembang dan terus mengalami peningkatan yang signifikan sampai sekarang. Dari aspek akuntansi, perlakuan sukuk di Indonesia diatur oleh PSAK 110 yang sudah mengakomodir kebutuhan pemahaman antara penerbit sukuk dan pengguna sukuk. Sementara dari aspek hukum, meskipun saat ini payung hukum untuk penerbitan sukuk di Indonesia sudah memadai karena sudah diatur oleh Undang-Undang, Peraturan Pemerintah, Peraturan Menteri Keuangan, bahkan hingga Peraturan Otoritas Jasa Keuangan, namun masih perlu dilakukan penguatan kerangka hukum melalui penyempurnaan pokok kebijakan yang sudah ada. Akan tetapi, dibalik peningkatan sukuk yang signifikan, penerbitan sukuk masih mengalami beberapa kendala yakni tidak adanya standardisasi fatwa mengenai struktur produk-produk instrument syariah dari masingmasing negara dan standar AAOIFI belum digunakan sebagai acuan, kurangnya pemahaman masyarakat akan keberadaan sukuk, dan faktor promosi dan iklan dalam dunia investasi di pasar modal serta bermacam macam jenis akad yang mendasari penerbitan sukuk.

\section{KETERBATASAN}

Keterbatasan dalam penelitian ini antara lain terbatasnya literatur ilmiah relevan yang up to date, sementara permasalahan yang dibahas sedang berkembang pesat saat ini. Selain itu, pembahasan hasil pada penelitian ini berupa narasi yang didalamnya masih terdapat unsur subjektivitas. Selain itu, ruang lingkup yang dibahas dalam penelitian ini masih terbatas. Penelitian selanjutnya dapat mengelaborasi ulasan melalui wawancara dengan para ahli baik dari akademisi dan praktisi untuk mendapatkan hasil yang lebih komprehensif dan lebih objektif.

\section{IMPLIKASI}

Dari hasil pembahasan yang telah dilakukan, Pemerintah maupun perusahaan penerbit SBSN diharapkan untuk meningkatkan promosi dan iklan mengenai sukuk. Hal ini dilakukan untuk memberikan edukasi dan pemahaman masyarakat tentang sukuk. Meningkatnya pemahaman dan pengetahuan masyarakat, diharapkan mampu menarik minat masyarakat untuk berinvestasi melalui sukuk.

Dari aspek hukum perpajakan diharapkan dapat memberikan payung hukum yang jelas dan pasti. Karena, keuntungan (return) dari obligasi konvensional berbeda dengan obligasi syariah (sukuk) sehingga dapat menurunkan minat masyarakat terhadap sukuk atau dapat menimbulkan double taxation terhadap obyek pajak yang sama.

\section{DAFTAR PUSTAKA}

Abubakar, L. (2017). Kesiapan Infrastruktur Hukum Dalam Penerbitan SUKUK (Surat Berharga Syariah) Sebagai Instrumen Pembiayaan dan Investasi Untuk Mendorong Pertumbuhan Pasar Modal Syariah Indonesia. Jurnal Jurisprudence, 7(1), 1-14.

Adrian, N., Muharam, H. (2011). Analisis FaktorFaktor yang Mempengaruhi Peringkat Obligasi Pada Perusahaan Manufaktur yang terdaftar di Bursa Efek Indonesia, Skripsi Diterbitkan, Universitas Diponegoro.

Armadiyanti, P. (2013). Peluang dan Tantangan Perkembangan Obligasi Syariah (SUKUK) Di Indonesia. Jurnal Akuntansi AKUNESA, 2(1), 1-20.

Azwar. (2014). Pengaruh Penerbitan Sukuk Negara Sebagai Pembiayaan Defisit Fiskal Dan Kondisi Ekonomi Makro Terhadap Perkembangan Perbankan Syariah Di Indonesia. Jurnal Of Info Artha Sekolah Tinggi Akuntansi Negara (STAN), 2(9), 1-21.

Beik, I. S. (2011). Memperkuat Peran SUKUK Negara Dalam Pembangunan Ekonomi Indonesia. Jurnal Ekonomi Islam Al-Infaq, 2(2), 65-72.

Brigham, E., Eugene, F., Houston, J. F. (2018). Dasar-Dasar Manajemen Keuangan (Buku 1) (Edisi 14). Jakarta: Salemba Empat.

Kurniawati, D. D. (2014). Analisis Perkembangan Sukuk (Obligasi Syariah) Dan Dampaknya 
Bagi Pasar Modal Syariah. Jurnal Akuntansi AKUNESA, 1-23.

Faniyah, I. (2018). Kepastian Hukum Sukuk Negara sebagai Instrumen Investasi Di Indonesia. Yogyakarta: CV Budi Utama.

Fasa, M. I. (2016). Sukuk: Teori dan Implementasi. Jurnal Studi Ekonomi dan Bisnis Islam, 1(1), 80-94.

Fatah, D. A. (2011). Perkembangan Obligasi (sukuk) Di Indonesia: Analisis Peluang dan Tantangan. Jurnal AL 'Adalah, 10(1), 35-46.

Harahap, A. T. (2017). Perkembangan Akuntansi Syariah di Indonesia. Majalah Ilmiah Warta Dharmawangsa, 53, 1-14

Hasibuan, A. A. (2014). Sejarah Perkembangan Akuntansi Syariah di Indonesia. Dikutip dari http://www.academia.edu/download/417564 10/SEJARAH_PERKEMBANGAN_AKUN TANSI_SYARIAH_DI_INDONESIA.docX 30 Agustus 2019, 20.00 WIB.

Hudiata, E. (2017). Rekonstruksi Hukum Penyelesaian Sengketa Pasar Modal Syariah: Penguatan Aspek Regulasi Untuk Memberikan Kepastian Hukum. Jurnal Hukum dan Peradilan, 6(2). 297-316.

IAIN Kendari. (2016). Analisis Perkembangan SUKUK di Indonesia. Dikutip dari https://studyclubiainkendari.wordpress.com/ 2016/12/23/analisis-perkembangan-sukukdi-indonesia/ 30 Agustus 2019, 21.00 WIB.

Jakarsih, M., Rusydiana, A. S. (2009). Perkembangan Pasar Sukuk: Perbandingan Indonesia, Malaysia, Dan Dunia. Jurnal Bisnis dan Ekonomi: Antisipasi, Universitas Sanata Dharma, 1(2), 1-18.

Maharti, E. D. (2011). Analisis Faktor Faktor yang Memengaruhi Peringkat Obligasi. Skripsi diterbitkan. Universitas Diponegoro.

Pew Research Center's Forum on Religion \& Public Life. (2019). Data populasi penduduk. Dikutip dari http://globalreligiousfutures.org/exp lorer/custom\#/?subtopic=15\&countri es=Worldwide\&chartType=pie\&data type $=$ number \&year $=2020 \&$ religious_a ffiliation $=$ all\&age_group $=$ all\&pdfMo $\underline{\mathrm{de}}=$ false\&gender $=$ all 30 Agustus 2019, 22.00 WIB.

Syariah, D. P. (2017). Tanya Jawab Surat Berharga Syariah / sukuk negara. Dikutip dari

https://www.djppr.kemenkeu.go.id/ uploads/files/dmodata/in/6Publikas i/5Brosur/Buku_Tanya_Jawab_SBSN Edisi_Kedua_2010.pdf 31 Agustus 2019, 09.00 WIB.

Zakiya, B. U. \& Siswantoro, D. (2014). Analisis Perlakuan Akuntansi Surat Berharga Syariah Negara Berdasarkan PSAK 110 Tentang
Akuntansi sukuk. Jurnal Fakultas ekonomi

Universitas Indonesia, 1-20.

\section{UCAPAN TERIMA KASIH}

Alhamdulillah, puji syukur panjatkan kehadirat Allah SWT atas berkat rahmatnya penulis mampu menyelesaikan tulisan sederhana ini pada waktu yang tepat.

Rasa Terima Kasih kami haturkan kepada

1. Pak Amrie Firmansyah selaku dosen Politeknik Keuangan Negara STAN yang telah memberikan wawasan, motivasi, dan Ilmu yang sangat bermanfaat untuk masa depan.

2. Mas Eko Hadi kusuma, selaku mahasiswa (teman kelas), yang memberikan dukungan untuk dapat menyelesaikan tulisan ini

3. Teman -teman kelas 903 Program DIV Akuntansi (Non AKT) yang memberikan berbagai ide dan dukungan selama menulis.

Semoga atas dukungan dan kerjasamanya dapat mendapatkan balasan yang lebih baik oleh Allah SWT dan menjadi amal jariyah yang tiada putus kelak di akhirat.

Penulis menyadari bahwa tulisan sederhana ini jauh dari sempurna. Oleh karena itu, penulis mengharapkan kritik dan saran yang membangun dari semua pembaca. 